\title{
名城大学理工学部における数学基礎教育の 改善と効果検証
}

Improvement of Mathematical Education in Faculty of Science and Technology, Meijo University and Verification of its Effects

$\begin{array}{cl}\text { 松 本 幸 } \text { 正 }^{* 1} & \text { 鈴 木 } \quad \text { 温 }{ }^{* 1} \\ \text { Yukimasa MATSUMOT0 } & \text { Atsushi SUZUKI }\end{array}$

\begin{abstract}
Although the academic ability in science such as Mathematics, Physics and Chemistry is indispensable for Engineers, the fundamental ability of freshmen in Science has recently seemed to become lower and lower. The investigation was therefore conducted to grasp what subjects on science they've learned before entering the university by Center for Educational Development in Science and Technology in Meijo University. This reveals that a part of freshmen has not learned the indispensable subjects to study in the university. According to the result of this investigation, the mathematical education has been first improved with the objective to raise the level of the ability of freshmen with low mathematical ability. As a result, the improvement of mathematical education yields positive effects on the freshmen with the low ability.
\end{abstract}

Keywords : Fundamental Academic Ability in Science, Mathematics Education, Freshman Education, Educational Effect, Engineering Education

キーワード : 理数基礎学力, 数学教育, フレッシュマン教育, 教育効果, 技術者教育

\section{1.はじめに}

産業技術の世界的な集積地である中部地区に位置す る名城大学理工学部は, 大正15年の開設以来, モノづ くりを通して, 地域産業の発展と活性化に貢献する技 術者を輩出し続けてきた。 今後とも，モノづくり産業 を支え続ける優秀な技術者の輩出が，本学部の大きな 使命の 1 つといえる.

技術系の専門知識を養うためには理数基礎知識は不 可欠であり, 専門教育においては, それらは既に習得 しているものとして講義が進められる.しかしながら, 昨今, 本学部への入学者の理数基礎学力の低下が目に つくようになってきた，具体的には，新入生の理数基 礎学力と本学部の理数基礎教育に関して, 以下のよう な問題が表面化してきている.

(1) 大学での学習に必要な理数基礎知識を高等学校で 習熟していない学生が目に付き始めた

（2）理数基礎学力が全体的に低下しつつある

（3）理数基礎学力が高い学生の力を伸ばしきれていな い

これら以外にも， 1 年次に学習した理数科目の知識 を専門科目で活かせていないといったことも問題と

平成 22 年 2 月 23 日受付

*1名城大学理工学部
なっている.

このような問題への対応として, まずは, 理工学部 の各専門教育において最も重要かつ基礎となる数学を 対象とし, 教育システムの大幅な見直しについて検討 し, 平成 20 年度から, その改善方策を実施に移した. また, 新入生の実態を捉えるため, 全新入生を対象と して, 高等学校までの理数科目の学習履歴を本格的に 調查した.

本稿では, はじめに, 数学教育の改善を検討した理 工学教育推進センターの概要を示し, 続いて, 本学部 における新入生の理数科目に関する学習の現状を報告 する.ささらに, 本学部で実施に移した数学教育の改善 方策の内容を示すとともに, それらの効果を具体的に 検証していく.

\section{2. 名城大学理工学部理工学教育推進センター}

\section{1 名城大学理工学部の概要}

名城大学理工学部 (以下, 本学部と略す) には, 理 学系の学科として数学科が 1 学科, 工学系の学科とし て情報工学科, 電気電子工学科, 材料機能工学科, 機 械システム工学科, 交通科学科, 建設システム工学科, 環境創造学科, 建築学科の計 8 学科があり, 1 学年の 学生定員の合計は1,105名で, 18のクラスに分けられ ている. 


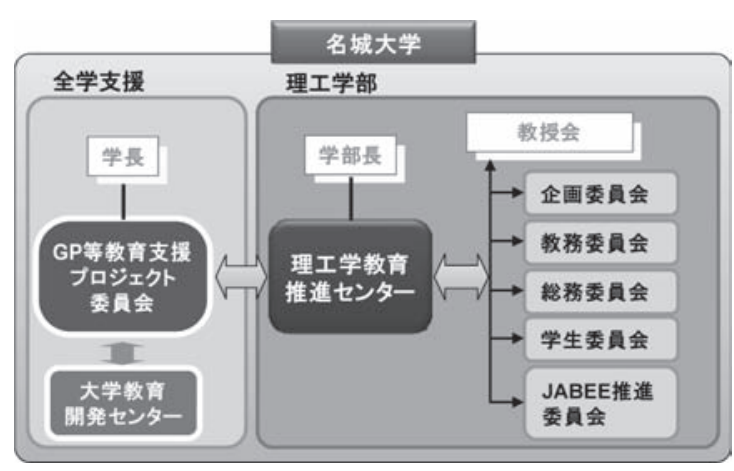

図 1 理工学教育推進センターの大学での位置づけ

本学部の工学系の入学試験は, 学科別入試と系入試 の大きく 2 つに分けられ，募集定員は 7 対 3 となって いる. 系入試で入学した学生は配属学科が決まってお らず， 1 年間の導入教育を経た上で, 成績を加味して 希望によって 2 年次から学科に配属される。したがっ て, 1 年次には, 学科が決まっている学生と学科が決 まっていない学生が混在することになる。本学部で は， 1 年次を技術者としての基礎的な教育期間と位置 づけ，専門の違いによらず共通かつ基礎的な教育内容 でカリキュラムを構成し, 学部で統一した内容として いる. 本稿で対象とする数学 I, 数学 II, 数学 III, 数 学 IV, 物理学 I, 物理学 II, 化学 I, 化学 II どは全 て 1 年次の科目である.

\section{2 理工学教育推進センターの概要}

理工学部としての教育的取組は, 従来, 理工学部教 務委員会を中心に検討し，実施していた．しかしなが ら, 教務委員会としてのルーチンワークのみでも負荷 は小さくなく, 新たな教育的課題への対応は必ずしも 十分とはいえなかった.

そこで, 変化する新たな教育的課題に傾注し, 迅速 で専門的な対応を図るため，平成19年 6 月に，「理工 学教育推進センター」を開設し, 学部としての新たな 教育的取組を推進するに至った，本センターの位置づ けを図 1 に示す. 本センターは, 全学と連携しながら, 理工学部 9 学科を取りまとめて教育的取組を牽引する 役割を担っている。

センターには，9学科から各 1 名の教員, 教養教育 および物理教室から各 1 名の教員, 教務委員長, 全学 の総合数理教育センター長, 全学委員会のGP等教育 支援プロジェクト委員会委員が参画している。また， 理工学部事務, 全学の学務センター, 全学の大学教育 開発センターの事務職員も委員として参画して打り, 教学組織と事務組織で連携を深めながら, 理工学部 1 年生の教育的取組を推進している.

\section{3. 新入生の理数科目に関する学習の現状}

$\mathrm{AO}$ 入試や推薦入試の拡大は, 多様な資質を持った 学生を集めることができる一方で，大学の学習に必 要な理数基礎知識を学習していないという現状が報
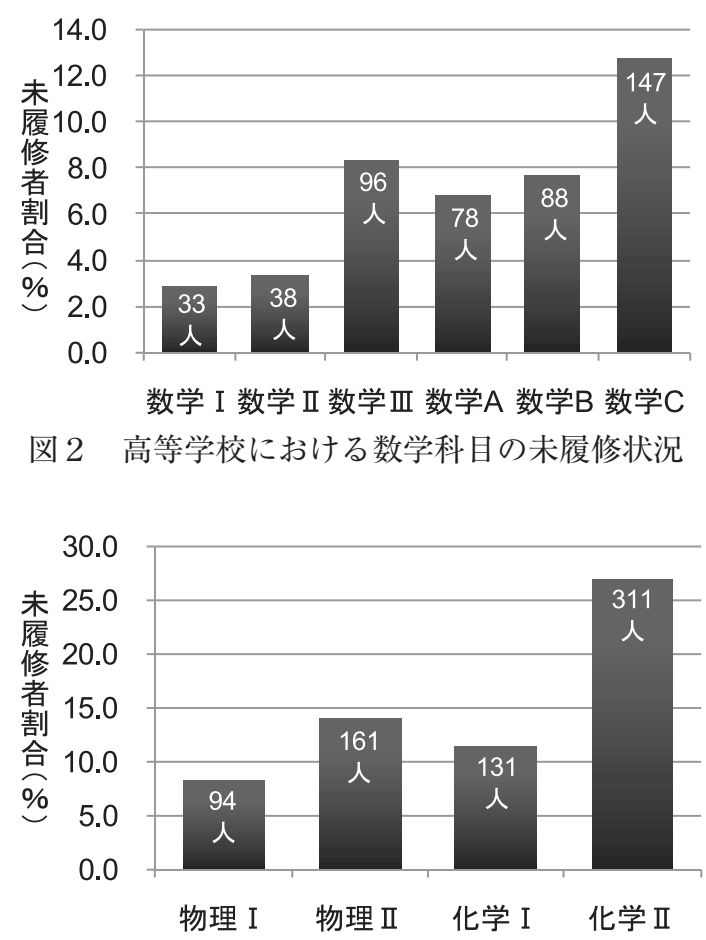

図 3 高等学校における理科科目の未履修状況

告 ${ }^{1), 2)}$ されている. 本学部においても状況は同様で あり, 新入生が高等学校において, 理数科目をどのよ うに履修してきているかを明らかにするため, 数学・ 物理学・化学の学習状況調查を実施した. 同時に, 大 学での理数科目の学習に対してどのように感じている かも把握した。調查は, 平成20年7月26日に実施し, 1,158 名の回答（留年生等を含む. 新入生に対する回 答率は93.3\%）を得た。

高等学校における数学科目の未履修の状況を図 2 に 示す. 数学 I ・ II に関してはほとんどの学生が履修し てきていることがわかるが, 数学 III で8.3\% (96名), 数学 Cで12.7\%（147名）の学生が未履修となってい る状況がわかる. 図 3 の理科科目の未履修状況を見て みると, 物理 I で8.1\%（94名), 物理 II で13.9\%（161 名), 化学 I で11.3\% (131名), 化学 II で26.9\%（311名） の学生が未履修であることが判明した，入試種別で見 た場合, 数学 IIIの未履修者の割合は, 専門高校の指定 校推薦で $91.5 \%$ と最も高く, 次いで専門高校の公募推 薦で $59.3 \%$, 普通科の公募推薦で $14.7 \%$ と続く. 同様 に, 物理 II では, 専門高校指定校推萀で $93.2 \%$, 専門 高校公募推薦で $55.6 \%$, 普通科指定校推薦で $18.3 \%$ と 続く. 化学 II では, 専門高校指定校推薦で $94.9 \%$, 附 属高校総合学科の推薦で $92.7 \%$, 専門高校公募推薦で $74.1 \%$ 続く。このように, 未履修者は, 専門高校の 推薦（指定校推薦と公募推薦）で特に多く, 普通高校 の推薦 (指定校推薦と公募推薦) が続いており, 推薦 入試によって入学した学生への対応策が必要であるこ とがわかった.

大学に抒いて, 高等学校の科目の補習をどれほど必 要としているかを知るため, 『大学で, 高等学校の理 


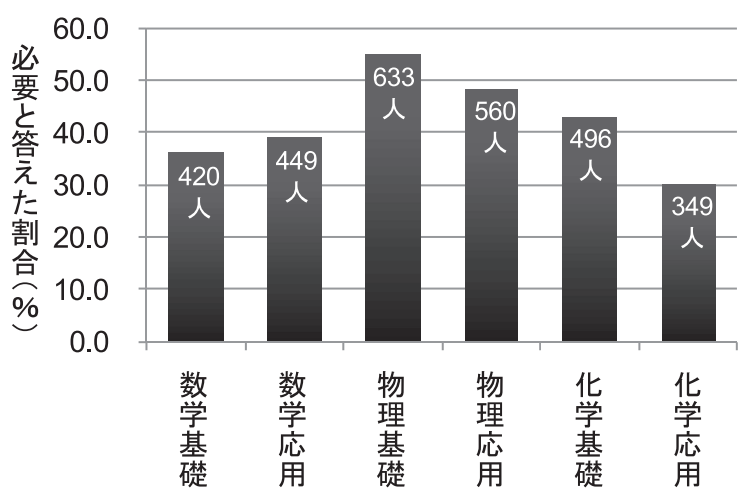

図 4 大学における理数科目の補習の必要性

数科目の学習内容を補習すること(大学の講義とは別. 単位は認められません）が，あなたには必要だと思い ますか.』との設問を設けた。図 4 にその結果を示す. 最も必要性の高かったものは「高校物理の基礎部分」 で, 過半数の $55 \%$ 学生が必要と感じており, 次いで, 「高校物理の応用部分」が48\%,「高校化学の基礎部分」 が $43 \%$ と続く結果となった．数学の補習に関する必要 性は，相対的に低い值になったが，それでも40\%弱の 学生は必要性を感じていることがわかり, 高等学校の 理数科目の補習に対する学生の要望の高さが明らかに なった.

今回の調査結果から, 大学での学習に必要な高等学 校までの理数科目の知識を十分に習得してこなかった 学生が約100名以上はいることが明らかとなり，また， 約 $40 \%$ 以上の学生が, 高等学校の理数科目の補習を必 要と考えていることも把握できた。これらの実態を踏 まえた教育的取組が不可欠であるといえる。

\section{4. 数学教育改善方策の内容と実施概要}

理数科目の中でも, 数学は技術者教育にとって最も 基本的かつ重要な科目であるとともに, 本学部には数
学科があるという強みを活かせることから, まずは, 数学教育を改善することにした，本学部における 1 年 次の数学科目には, 数学 I, 数学 II, 数学 III, 数学 $\mathrm{IV}$ がある. 数学 I および数学 II は前期科目であり, それ ぞれ解析学, 線形代数学を教え, 数学 III および数学 $\mathrm{IV}$ は後期科目で, 数学 III は数学 I, 数学 IV は数学 IIに続 く科目となっている.

平成 20 年度から実施に移した数学教育の改善内容を 前期科目の部分について図 5 に示す。改善の主な目的 は, 数学力の全体的な底上げ, 高等学校数学が未習熟 な学生への対応, 数学的基礎学力の高い学生のさらな る能力向上などである. 以下, 順にその内容を説明し ていく.

\section{1 数学教育の改善内容}

(1) 数学基礎知識習熟度自己診断テス卜

高等学校までに習得した数学の基礎学力を確認して もらうとともに, 数学基礎演習の受講判断の材料にし てもらうため, 入学直後に全 1 年生を対象にしたマー ク式の自己診断テストを導入した。このテストは，入 学式に続いて行われる新入生オリエンテーションで配 布される. 問題は, 高校数学を網羅するように60題設 定されているが，それぞれの問題を実際に解いてもら うのではなく, 問題を見て,「全くわからない（1点)」, 「解く自信はないが類似の問題なら解いたことがある ( 2 点) 」,「この問題を解くことができると思う ( 3 点)」 のいずれであるかを判断してもらうものである. 合計 点は, 最低で60点, 最高で180点となる.

新入生はこの問題を持ち帰って回答し, 数日後に提 出する. 提出された回答は直ちに集計され, 数学基礎 演習(補習コース)の受講を必要とする基準点を定める. 集計結果と補習コース受講の基準点は, 履修登録前ま でに掲示板と学生ポータルサイトで揭示し, 基準点以 下であった新入生には, 補習コースを受講してもらう.

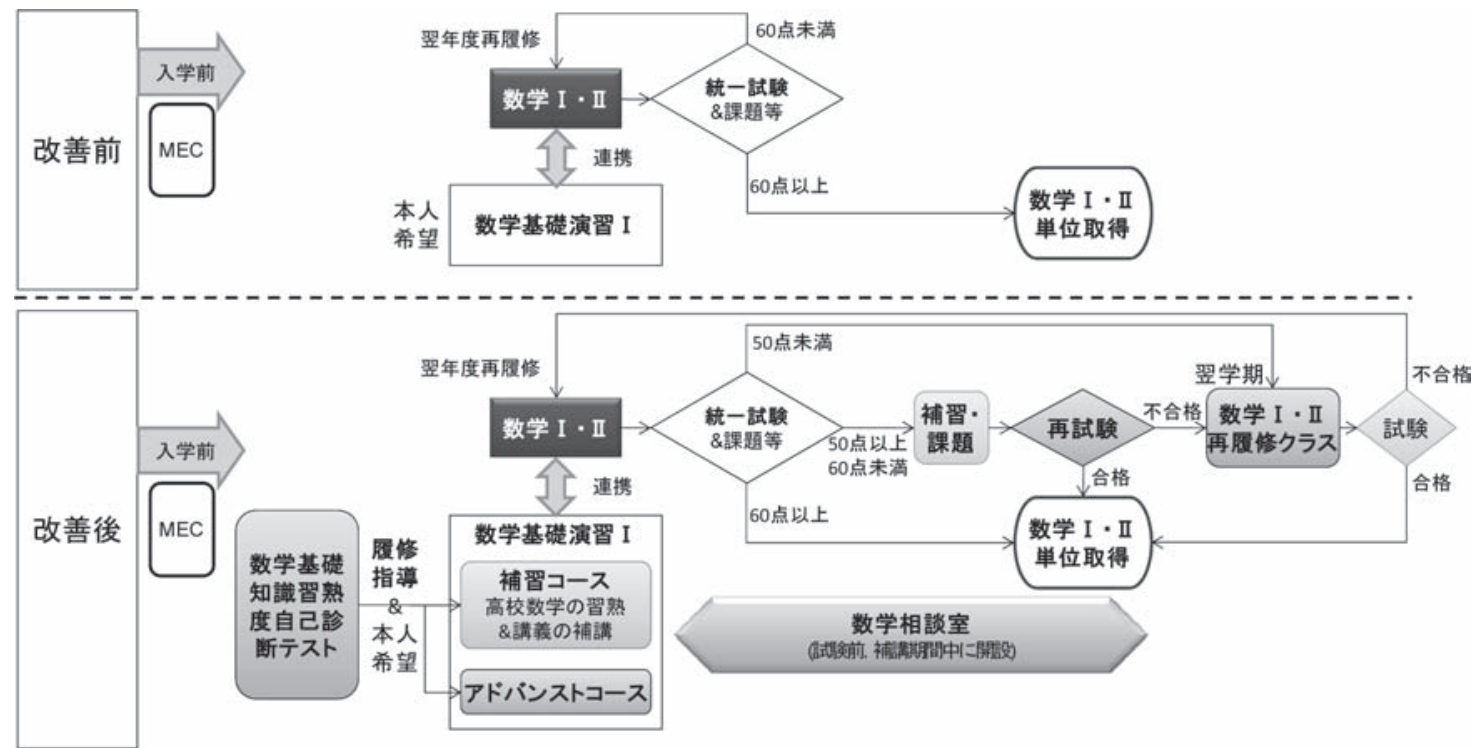

図 5 理工学部における数学教育の改善内容（前期科目部分） 
（2）数学基礎演習（補習コース）の内容変更

数学基礎演習 I （前期）と同 II (後期) は，これま でにも開講されていた自由科目（単位を修得しても, 卒業に必要な単位としては数えられない科目）である が, 平成 20 年度からは, 高校数学の補習と大学の数学 の講義の補講を行う科目として内容を変更した．数学 基礎知識習熟度自己診断テストの点数が基準点以下で あった学生は, 強制力はないが, この科目を履修しな ければならない。

（3）数学基礎演習（アドバンストコース）の開講

数学基礎学力の高い学生のさらなる能力引き上げを 目指して, 通常の数学の講義よりも応用的な内容を教 授する数学基礎演習 I（アドバンストコース）(前期), 同 II（後期）を開講した。この科目の履修には条件は なく，本人の希望による.

(4) 再試験制度の導入

定期試験の結果, 学習到達目標の達成度が少しだけ 足りなかった学生 (50点以上60点未満) を対象として, 再試験用の補習を受講して課題を提出した後に, 再試 験を受験できるようにした，再試験の受験は，本人の 希望による。この再試験の導入によって，これまで以 上の高い水準での成績評価が可能となり, 全体的な学 力の底上げにつながると考えられる。

(5) 翌学期における再履修専用クラスの開講

本学部の場合, 不合格となった科目を再履修するに は翌年度の同学期での受講が必要となる。このため, 習った内容を忘れてしまったり，不合格となった科目 より進んだ内容を先に学習することにより，再履修科 目に対する学習意欲が低下したりするなどの問題が懸 念されていた．これらの問題を解決すべく，数学に関 してのみ，翌学期に再履修クラスを開講することにし た.この再履修専用クラスは通常クラスとは異なり, その科目を少なくとも 1 回は学習していることを前提 とした講義内容となっているとともに, 少人数で行わ れるために教育効果が高いと考えられる.

(6) 数学相談室の開設

数学について, わからない点などがあったときに気 軽に教員に聞けるような場があれば, 数学の学習に対 するやる気を持続させることができると思われる，そ こでまずは，学生が勉強を集中的に行うであろう定期 試験前と再試験のための補習期間中に, 数学相談室を 開設することにした．この相談室として，相談しやす い環境が整備された専用の部屋を準備し, 昼休みや学 生の講義がない時間帯に開室した。学生からの相談に は, 開室時間帯に常駐している教員と大学院生が丁寧 に対応した。

（7）その他の取組

平成 20 年度より前から導入している教育的取組とし て, 統一試験の実施がある。数学の講義は， 1 年生を 18のクラスに分けて行うため, 担当者の違いなどから

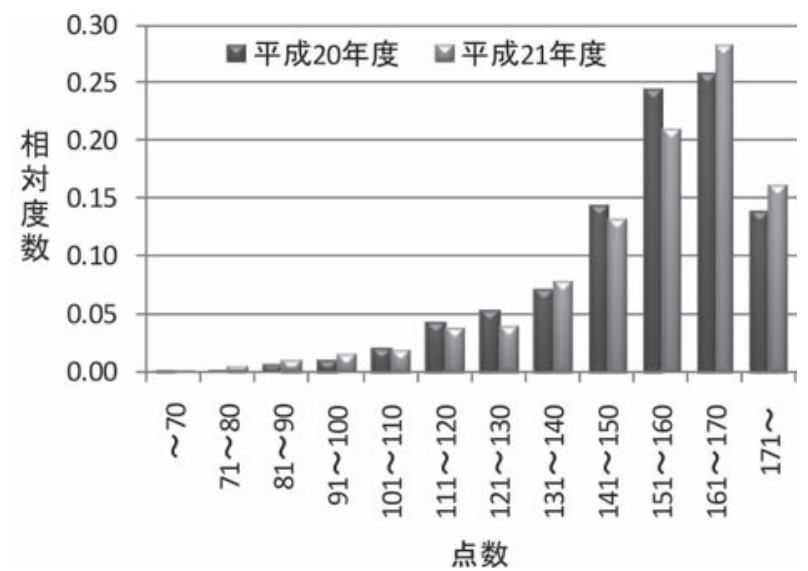

図 6 数学基礎知識習熟度自己診断テストの結果

クラスによるバラツキが出る恐れがある，そこで，定 期試験として問題が同一の統一試験を全クラスに受け させ，数学力の質保証を行っている.

他にも, 大学全体の教育的取組として, 推薦入学で 合格した受験生を主な対象として，入学までの期間に 学習支援を行うプログラム（MECと呼称）を実施し ている. プログラムは, オリエンテーション, 自宅学 習, スクーリングの 3 つで構成され, 数学, 物理学, 化学（他に, 英語や日本語もあり) に関する科目が開 設されている. 本学部に推薦で入学した学生は, 高等 学校の理数科目の未履修者が多いことが明らかになっ ているが, このMECプログラムによって, 高等学校 で学ぶ理数基礎知識を補うことが可能となっている.

\section{2 数学教育改善の実施結果}

改善方策の実施結果をまとめるにあたって, 数学が 専門となる数学科の学生は除外するとともに, 留年生 なども対象から外す。また, 退学や除籍などによって, デー夕入手時点の学籍にない学生も含まれていない.

（1）数学基礎知識習熟度自己診断テス卜

数学基礎知識習熟度自己診断テストの結果を図 6 に 示す. 平成 20 年度と平成 21 年度の分布に大きな違いは 見られない. 平均点はそれぞれ151.9点と152.6点とな り, ウィルコクスン検定の結果, 有意水準 $5 \%$ で両平 均点に差は認められなかった。この結果から, 平成 20 年度と平成 21 年度の新入生の数学の学力には, 变化は ないと判断できる.

自己診断テストの結果と補習コースの受け入れ可能 人数から, 数学基礎演習 (補習コース) の履修の判断 となる基準点を両年度とも144点とした. 対象学生数 は, 平成 20 年度が 284 人, 平成 21 年度が 252 人である.

（2）数学基礎演習（補習コース）

数学基礎演習（補習コース）の履修状況を表 1 に示 す.

平成 20 年度における補習コースの履修状況は, 前期 が 238 人, 後期が 232 人であり, 対前年度比で 3 割以上 の増加となり, 自己診断テス卜導入の効果が現れてい る. ただし, 基準点以下の学生のうち補習コースを履 
表 1 数学基礎演習（補習コース）の履修状況

\begin{tabular}{|c|c|c|c|}
\hline 年度 & $\begin{array}{c}\text { 基準点以下の } \\
\text { 学生数(人) }\end{array}$ & $\begin{array}{c}\text { 基礎演習 I の } \\
\text { 履修者数 (人) }\end{array}$ & $\begin{array}{c}\text { 基礎演習 II の } \\
\text { 履修者数(人) }\end{array}$ \\
\hline 平19年度 & - & 181 & 157 \\
\hline 平20年度 & 284 & $238(47.9 \%)$ & $232(46.5 \%)$ \\
\hline 平21年度 & 252 & $270(65.5 \%)$ & $228(53.6 \%)$ \\
\hline
\end{tabular}

（）内は，基準点以下の学生の履修割合

修している割合は, 前後期ともに $47 \%$ 前後と高くなく， 補習を受けるべき学生が受講していないという結果と なった，これは，平成20年度においては基準点以下の 学生には補習コースの受講を锥めるだけに留めたため であると思われる。この結果を受け，平成21年度から は, 基準点以下の学生に対しては, 強制力はないもの の，補習コースを必ず受講するように指導した。

平成21年度における補習コースの履修状況は，前期 で 270 人，後期で 228 人と，前期で前年度を 32 名上回る とともに，基準点以下の学生が履修する割合は前期で 約 $66 \%$, 後期で約 $54 \%$ と改善された.

（3）数学基礎演習（アドバンストコース）

平成20年度に新設されたアドバンストコースの受講 生は, 前期で 16 名, 後期で 12 名と非常に少なかった. そこで，平成 21 年度には，新入生オリエンテーション でアドバンストコースの存在を宣伝することにした． その結果, 前期で 25 名, 後期で 22 名と前年度よりも増 加した．この人数に関しては，少ないという意見と， ちょうど良いという意見が出されたが，まずは，少人 数のトップランナーを育てていこうということで意見 の一致をみた

表 2 数学科目の実施結果

\begin{tabular}{|c|c|c|c|c|c|c|}
\hline \multirow{2}{*}{ 科目 } & \multirow{2}{*}{ 年度 } & \multirow{2}{*}{ 合格率 } & \multicolumn{2}{|c|}{ 再試験 } & \multicolumn{2}{|c|}{ 再履修クラス } \\
\hline & & & 対象者 & 申請者 & 対象者 & 登録者 \\
\hline \multirow{3}{*}{$\begin{array}{l}\text { 数学 I } \\
\text { (前期) }\end{array}$} & 19 & 0.95 & - & - & - & - \\
\hline & 20 & 0.93 & 46 & $\begin{array}{c}23 \\
(50 \%)\end{array}$ & 69 & $\begin{array}{c}43 \\
(62 \%)\end{array}$ \\
\hline & 21 & 0.89 & 65 & $\begin{array}{c}45 \\
(69 \%) \\
\end{array}$ & 83 & $\begin{array}{c}57 \\
(69 \%) \\
\end{array}$ \\
\hline \multirow{3}{*}{$\begin{array}{l}\text { 数学 II } \\
\text { (前期) }\end{array}$} & 19 & 0.99 & - & - & - & - \\
\hline & 20 & 0.97 & 26 & $\begin{array}{c}9 \\
(35 \%) \\
\end{array}$ & 43 & $\begin{array}{c}19 \\
(44 \%) \\
\end{array}$ \\
\hline & 21 & 0.71 & 163 & $\begin{array}{c}101 \\
(62 \%)\end{array}$ & 204 & $\begin{array}{c}170 \\
(83 \%)\end{array}$ \\
\hline \multirow{3}{*}{$\begin{array}{l}\text { 数学 III } \\
\text { (後期) }\end{array}$} & 19 & 0.85 & - & - & - & - \\
\hline & 20 & 0.78 & 135 & $\begin{array}{c}94 \\
(70 \%) \\
\end{array}$ & 211 & $\begin{array}{c}137 \\
(65 \%) \\
\end{array}$ \\
\hline & 21 & 0.70 & 176 & - & - & - \\
\hline \multirow{3}{*}{$\begin{array}{l}\text { 数学IV } \\
\text { (後期) }\end{array}$} & 19 & 0.89 & - & - & - & - \\
\hline & 20 & 0.78 & 137 & $\begin{array}{c}99 \\
(72 \%)\end{array}$ & 173 & $\begin{array}{c}105 \\
(61 \%)\end{array}$ \\
\hline & 21 & 0.82 & 85 & - & - & - \\
\hline
\end{tabular}

\section{(4) 再試験}

数学に関する科目の実施結果を表 2 に示す.

合格率を見てみると，各科目で，年々低下している ことがわかる。これは再試験の導入と翌学期再履修ク ラスの開設によって，これまで以上に高い基準での成 績評価をした結果であると思われる。

再試験については，再試験制度を導入した平成20年 度の前期科目において, 受験率が数学 I で50\%, 数学 II で35\%と高くなかったが，後期では70\%以上に増加 している。平成21年度においては，再試対象者数も増 えたが，再試申請者は60\%以上となり，再試験制度が 機能してきたといえる.

（5）再履修専用クラス

再履修専用クラスの登録率は，対象者数が少なかっ た平成 20 年度の数学 II 以外では, 約 $60 \%$ 以上となって いることがわかる. 後期における再履修クラス（数学 I や数学 II ）の受講の場合, 内容的に進んだ他の数学 科目（数学 III や数学 IV）を並行して受講する必要があ るにもかかわらず高い受講率であるといえ, 落とした 単位をできるだけ早く取得しておきたいという学生の 要望にあった制度であるといえる。

（6）数学相談室

数学相談室は，平成20年度において，定期試験期間 中に 5 日間，再試験の期間に 2 日間ずつの計14日間開 室し，延べ 183 人の利用があった。平成 21 年度におい ては，前期定期試験期間の 5 日間および再試験期間の 1 日間の計 6 日間で，延べ56人の利用にとどまり，対 前年比で減少した。両年度とも, 学生数に比較して利 用者が多いとはいえず，先行事例 ${ }^{3)}$ を参考に，利用 者の増進を図っていく必要がある.

\section{5. 数学教育改善の効果検証}

本章においても, 数学科の学生は除外するとともに, 留年生や，デー夕入手時点での退学者や除籍者なども 含めない.

（1）数学基礎知識習熟度自己診断テスト

数学基礎知識習熟度自己診断テストの妥当性を見る ため, 大学入学時までに履修した数学科目の違いが, テストの平均点に影響を及ぼしているかを一元配置分

表 3 高校数学の履修別の自己診断テストの平均点

\begin{tabular}{|c|c|c|c|}
\hline $\begin{array}{c}\text { 高校数学 } \\
\text { の科目 }\end{array}$ & $\begin{array}{c}\text { 履修者の } \\
\text { 平均点 }\end{array}$ & $\begin{array}{c}\text { 未履修者の } \\
\text { 平均点 }\end{array}$ & 主効果の判定 \\
\hline 数学 I & 152.0 & 148.0 & \\
\hline 数学 II & 152.4 & 136.5 & $* *$ \\
\hline 数学 III & 154.3 & 124.3 & ** \\
\hline 数学 $\mathrm{A}$ & 153.5 & 127.8 & $* *$ \\
\hline 数学 $\mathrm{B}$ & 154.0 & 126.2 & $* *$ \\
\hline 数学 $\mathrm{C}$ & 155.2 & 128.2 & $* *$ \\
\hline
\end{tabular}


表 4 数学基礎演習（補習コース）の履修状況別の成績

\begin{tabular}{|c|c|c|c|c|}
\hline \multirow[b]{2}{*}{ 科目 } & \multirow[b]{2}{*}{ 年度 } & \multirow[b]{2}{*}{$\begin{array}{c}\text { 補習コース } \\
\text { 非対象者 }\end{array}$} & \multicolumn{2}{|c|}{ 補習コース対象者 } \\
\hline & & & $\begin{array}{c}\text { 基礎演習 } \\
\text { 合格 }\end{array}$ & $\begin{array}{c}\text { 基礎演習 } \\
\text { 非履修 }\end{array}$ \\
\hline \multirow{2}{*}{ 数学 I } & 20 & 78.7 & 77.5 & $73.6^{*}$ \\
\hline & 21 & $78.7^{* *}$ & 71.9 & 69.8 \\
\hline \multirow{2}{*}{ 数学 II } & 20 & $82.8^{* *}$ & 86.3 & $77.7^{* *}$ \\
\hline & 21 & 66.3 & 66.8 & $59.7^{* *}$ \\
\hline \multirow{2}{*}{ 数学 III } & 20 & 68.9 & 68.9 & $61.5^{* *}$ \\
\hline & 21 & $66.9^{* *}$ & 60.9 & 57.5 \\
\hline \multirow{2}{*}{ 数学 IV } & 20 & 68.7 & 68.6 & $64.2^{*}$ \\
\hline & 21 & 72.1 & 72.5 & $64.6^{* *}$ \\
\hline
\end{tabular}

散分析によって分析した。その結果を表 3 に示す。こ の結果から, 数学 I を除いて, 高校数学の履修状況 が，自己診断テストの結果に差異をもたらしていると いえ, 本学部で用いている数学基礎知識習熟度自己診 断テストは, 高校数学の習熟状況を反映できると判断 できる。したがって，自己診断テストの結果に基づい て数学基礎演習（補習コース）を履修すべき基準点を 設けることは，妥当であるといえる。

（2）数学基礎演習（補習コース）

数学基礎演習（補習コース）の履修状況と数学科目 の成績との関係を表 4 にまとめる.「補習コース対象 者」とは, 数学基礎知識習熟度自己診断テストの得点 が基準点以下の学生のことで, これらの学生をさらに 数学基礎演習（補習コース）を履修して合格した学生 と, 数学基礎演習（補習コース）を履修しなかった学 生とに分けて, 数学科目の成績の平均点を算出した. 補習コース対象者で数学基礎演習に合格した学生の数 学科目の平均点と, 他の学生の平均点の間に統計的に 有意な差があるかを見るため, Tukeyの方法により多 重比較を行った．表中で網掛けがしてあるところが, 補習コース対象者だが数学基礎演習を履修しなかった 学生との間で有意な差が認められた科目である。ほと んどの年度, 科目で有意差が見られ, 数学基礎演習（補 習コース）の履修によって数学の学力を補うことがで きているといえる。 また, 補習コース非対象者と比較 した結果も示してあるが, 平成21年度の数学 I および 数学 IIIで, 補習コース非対象者の平均点の方が統計的 に高いといえるが，その他の科目では両者の平均には 差がないといえる. 逆に, 平成 20 年度の数学Iににおい ては, 平均点が逆転している.これらのことから, 数 学基礎演習 (補習コース) は, 数学基礎学力の向上に 効果があったと判断できる.

（3）数学基礎演習（アドバンストコース）

平成 20 年度にアドバンストコースを受講して単位取 得した学生の数学科目の成績平均は, 数学 I が86.9 で, 数学 II が 88.4 となっている. 平成 21 年度はそれぞ
表 5 再試験の受験別の成績

\begin{tabular}{|c|c|c|c|}
\hline 科目 & 年度 & 再試の合格者 & 再試の非申請者 \\
\hline \multirow{2}{*}{ 数学 III } & 20 & 57.8 & 50.8 \\
\cline { 2 - 4 } & 21 & 52.6 & 50.3 \\
\hline \multirow{2}{*}{ 数学 $\mathrm{IV}$} & 20 & 58.4 & 51.8 \\
\cline { 2 - 4 } & 21 & 67.3 & 60.7 \\
\hline
\end{tabular}

表 6 再履修クラスの履修別の成績

\begin{tabular}{|c|c|c|c|}
\hline \multirow{2}{*}{ 科目 } & 年度 & $\begin{array}{c}\text { 再履修クラスの } \\
\text { 履修者 }\end{array}$ & $\begin{array}{c}\text { 再履修クラスの } \\
\text { 未履修者 }\end{array}$ \\
\hline \multirow{2}{*}{ 数学 III } & 20 & 48.9 & 49.3 \\
\cline { 2 - 4 } & 21 & 48.4 & 45.0 \\
\hline \multirow{2}{*}{ 数学 IV } & 20 & 46.9 & 53.0 \\
\cline { 2 - 4 } & 21 & 59.5 & 43.3 \\
\hline
\end{tabular}

れ，88.4と76.1となって扮り，表 4 の補習コース非対 象者の平均点と比べてもかなり高い. 同様に後期科目 となる数学 III と数学 $\mathrm{V}$ については, 平成 20 年度が 83.8 と 81.3 , 平成 21 年度が83.5と78.3となっており, 成績 優秀であることがわかる.これら高い平均点だけでは， 基礎演習（アドバンストコース）の効果を検証するこ とはできないが，トップランナーを育てるというねら いには合致しているといえる.

\section{(4) 再試験}

再試験の効果を検証するため, 前期科目を対象とし て, 再試験を受験して合格したグループと, 対象で あったが再試験を申請しなかった学生のグループを抽 出し, 続きとなる後期科目の成績平均点に違いがある かを見る. グループごとの平均点を表 5 に示す. 対象 者が多くないため統計的検定は省略するが，両年度の 両科目で, 再試験に合格した学生の平均点の方が高く なっていることがわかる. 再試験を受験するためには, 補習の受講と課題提出が義務づけられるため, 科目に 対する理解が深まり, その結果が続く後期科目の学習 に反映されたと考えることができる.

(5) 再履修専用クラス

再履修クラスの効果を検証するため, 前期科目の不 合格者を対象として, 後期の再履修専用クラスを履修 したグループと履修しなかったグループごとに, 続く 後期科目の成績平均点に違いがあるかを見る.グルー プごとの平均点を表 6 に示すが, 対象者が多くないた め統計的検定は省略している.

両年度の両科目で, 再履修専用クラスを履修してい る学生グループの方が, 続く後期科目の成績平均が悪 くなっていることわかる. これらの学生は, 数学吕や IV と同時に, 数学 I や数学 II 履修していることにな る. したがって, 前期の学習内容を十分理解していな い状態で, さらに進んだ内容も同時並行で学習しなけ ればならず, 習熟度の低い学生は消化不良を起こして いる可能性も否定できない.さらなるデー夕の収集や 対象学生の意見を聞くとともに，先行事例 ${ }^{4)}$ を参考 
にしながら，再履修専用クラスを再検討することが望 まれる。

\section{6. おわりに}

名城大学理工学部理工学教育推進センターでは, 数 学教育のシステムを大幅に見直し, 平成 20 年度から実 施に移した，その教育改善効果を分析した結果，多く の方策で教育的効果が認められることがわかった。一 方で，再履修専用クラスなどその効果が現れなかった 方策もあった，同時に，運用上での課題もいくつか浮 き彫りになっており, さらなる改善の検討が必要であ る. 今後は, 数学以外の理数基礎科目, 特に物理学の 教育改善に対する必要性ならびに要望が強いことか ら，早急な対応策が期待される。

なお本稿は, 著者ら個人の見解に基づくものであり， 理工学教育推進センターの見解ではない。 また, 教育 改善効果についても，著者らによる分析結果に基づく ものであり, センターとして検証した効果ではないこ とを付記する。

$$
\text { 参 考 文 献 }
$$

1) 岡本正行：工学教育における高校教育の重要性,
工学教育, $57-5$, p.2, 2009

2 ) 谷口 進, 西 誠: 工学基礎教育科目に扮ける教 育工夫 - 学生の学修履歴と物理, 化学系科目に対 する意識調查, 平成19年度工学・工業教育研究講 演会講演論文集, pp.512-513, 2008

3 ) 高橋哲也 : 大学初年次数学教育の再構築, 特色あ る大学教育支援プログラム事例集, pp.199-206, 2007

4) 古関義之: 福井大学工学部の初年次の数学教育, 工学教育, $57-5$, pp.13-16, 2009

\section{著 者 紹 介}

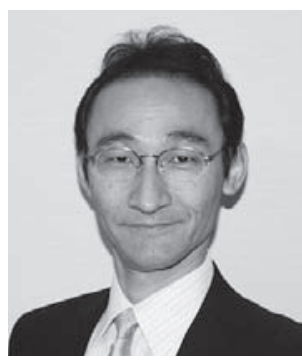

\section{松本 幸正}

1991年名古屋工業大学大学院工学研究科 博士前期課程修了. 名城大学理工学部助 手などを経て，2007年より名城大学理工 学部建設システム工学科教授. 専門は交 通工学・都市計画. 日本工学教育協会, 土木学会, 日本都市計画学会などに所属 博士 (工学), 技術士（建設部門）

matumoto@meijo-u.ac.jp 